\title{
Efficiency and selectivity of ionic liquids in microwave-assisted extraction of major lichen phenolic compounds: a scalable process with recycling of ionic liquids
}

\author{
Sarah Komaty ${ }^{1,2}$ | Aurélie Sauvager $^{1}$ | Jean-Pierre Bazureau ${ }^{1}$ ( ) | \\ Sophie Tomasi ${ }^{1}$ ( ) | Ludovic Paquin ${ }^{1}$
}

${ }^{1}$ CNRS, ISCR UMR 6226, University of Rennes, Rennes, France

${ }^{2}$ KAUST Catalysis Center (KCC), King Abdullah University of Science and Technology, Thuwal, Saudi Arabia

Correspondence

Sophie Tomasi and Ludovic Paquin, Institut des Sciences Chimiques de Rennes, UMR 6226, COrInt, Université de Rennes 1, 263 Avenue du Général Leclerc, 35042 Rennes Cedex, France.

Email: sophie.tomasi@univ-rennes1.fr; ludovic.paquin@univ-rennes1.fr

\begin{abstract}
Introduction: Pseudevernia furfuracea, a lichen used classically for cosmetic applications, contains interesting metabolites possessing antimicrobial and anti-inflammatory or antioxidant properties.
\end{abstract}

Objectives: Ionic liquid combined to microwave-assisted extraction (IL-MAE) was successfully applied for metabolites extraction from Pseudevernia furfuracea.

Materials and methods: Three imidazolium and pyridinium-based ionic liquids (ILs): 1,3-dimethylimidazolium methylsulphate $\left[\mathrm{C}_{1} \mathrm{C}_{1} \mathrm{Im}\right]\left[\mathrm{MeSO}_{4}\right]$, 1-ethyl-3-methy limidazolium ethylsulphate $\left[\mathrm{C}_{2} \mathrm{C}_{1} \mathrm{Im}\right]\left[\mathrm{EtSO}_{4}\right]$, and $\mathrm{N}$-ethylpyridinium ethylsulphate $\left[\mathrm{C}_{2} \mathrm{Py}\right]\left[\mathrm{EtSO}_{4}\right]$ were assessed for this process. The efficiency of the extraction method was evaluated using thin-layer chromatography (TLC) coupled to a Camag® spectrophotodensitometer and using high-performance liquid chromatography (HPLC) analysis.

Results: ILs under MAE showed extraction time efficiency (15 min vs. $24 \mathrm{~h}$ for conventional heating) and high selectivity in extracting the targeted metabolites: atranorin (AT), methyl- $\beta$-orcinol carboxylate (MOC), fumarprotocetraric acid (Fum. Ac.), and physodic acid (Phys. Ac.) despite the increased degradation of AT under MAE. We showed a tunable selectivity of ILs towards extracting metabolites by changing anion or cation due to the modification of the interaction between the IL and the metabolites. While $\left[\mathrm{C}_{2} \mathrm{Py}\right]\left[\mathrm{EtSO}_{4}\right]$ was the most efficient IL and could extract all the targeted metabolites, $\left[\mathrm{C}_{2} \mathrm{C}_{1} \mathrm{Im}\right]\left[\mathrm{EtSO}_{4}\right]$ was the most selective. It fully extracted AT and partially Fum. Ac. Moreover, the lichen prepared by mixing procedure provided AT and Fum. Ac. more than the milled one. A 100 times scale-up extraction was successfully performed on mixed samples with full IL recycling after back extraction.

Conclusion: IL-MAE is reliable for lichen metabolites extraction. The method is reproducible, scalable, with possible IL recycling, opening the door for potential industrial applications.

\section{KEYWORDS}

ionic liquid, lichens, microwave-assisted extraction (MAE), phenolic compounds, pilot-scale, Pseudevernia furfuracea, recycling of ionic liquids 


\section{1 | INTRODUCTION}

Lichens are a large group of symbiotic organisms with around 17000 reported species. ${ }^{1}$ These organisms, which are able to live in extreme conditions, produce different types of phenolic specialised metabolites including monophenolic compounds, depsides, depsidones, and diphenyl ethers for the most lichen-specific metabolites. ${ }^{2}$ Lichens are employed in various fields of application including perfumery, cosmetics, and for medicinal purposes ${ }^{3,4}$ owing to the interesting biological activities of their metabolites including antitumour, anti-inflammatory, antiviral, antibacterial or antioxidant (for review see the literature ${ }^{5-8}$ ). Extracting these metabolites in their pure form is of great interest. A potential candidate class of solvents to fulfil this task is the ionic liquids (ILs), attracting a growing interest in the extraction process for the isolation and/or purification of various bioactive compounds from biomass matrices ${ }^{9}$ or plants. ${ }^{10,11}$ ILs are solvents of interest for extraction processes due to their unique properties such as low vapour pressure, non-flammability, solvents miscibility, and good extractability of various compounds. ${ }^{9,11,12}$ Some disadvantages have been nevertheless revealed such as the potential environmental impact of some toxic ILs and the relatively high cost of large-scale industrial applications. It is thus necessary to consider low or non-toxic ILs and ensure their recovery at the end of the extraction process ${ }^{12}$ to reduce the economical and ecological costs. Thus, ionic liquid combined to microwave-assisted extraction (IL-MAE) was applied herein to Pseudevernia furfuracea (L.) Zopf, a lichen of high interest due to its richness in active phenolic compounds and its application in the perfume industry (1900 tons/ yr). ${ }^{13,14}$ Various extracts derived from this lichen already exhibited significant antimicrobial, anti-inflammatory, anticancer and antioxidant activities. ${ }^{15-17}$ The major isolated metabolites from Pseudevernia furfuracea are two depsides [atranorin (AT) and chloratranorin] and some depsidones [physodic acid (Phys. Ac.) or olivetoric acid according to the chemotype]. These latter metabolites (AT or Phys. Ac.) are known for their antimicrobial ${ }^{18,19}$ and anti-inflammatory ${ }^{20}$ or antioxidant ${ }^{21}$ properties. We have already studied the influence of sample preparation method (mixing or milling of lichens) on the efficiency of MAE using acetone to extract AT from Pseudevernia furfuracea var. furfuracea. ${ }^{14}$ We have also investigated the influence of the anion chain length on the extraction of norstictic acid from Pertusaria pseudocorallina using IL-based on imidazolium cation combined with microwave irradiation. ${ }^{22}$ An additional study was recently performed on Stereaucolon glareosum confirming the ability of imidazolium cations to interact with lichen metabolites. ${ }^{23}$

In this work, we explore various parameters influencing the ILMAE of four metabolites from Pseudevernia furfuracea var. furfuracea (Figure 1) including the method used to prepare the samples and the structure of ILs. Three different ILs bearing inorganic anions and pyridinium- or imidazolium-derived aromatic cations were assessed (Table 1). We explore the influence of these structural modifications of the ILs on the extraction efficiency of the major secondary metabolites from Pseudevernia furfuracea. Additionally, we report the successful 100 times scale up of the process with complete recycling of the IL.<smiles>CC(=O)c1c(C)cc(O)c(C)c1O</smiles>

methyl beta-orcinolcarboxylate (MOC)<smiles>Cc1c(C(=O)O)c(O)c(COC(=O)/C=C/C(=O)O)c2oc3c(C)cc(O)c(C)c3c3c(C)c(O)cc(C)c3oc12</smiles>

Fumarprotocetraric acid (Fum. Ac.)<smiles>COC(=O)c1c(C)cc(OC(=O)c2c(C)cc(O)c(C=O)c2O)c(C)c1O</smiles>

Atranorin (AT)<smiles>CCCCCC(=O)Cc1cc(O)cc(OC(=O)c2c(OCCCC)cc(O)c(C(=O)O)c2CCCC)c1C(=O)O</smiles>

Physodic acid (Phys. Ac.)
FIGURE 1 Targeted lichen metabolites

TABLE 1 Assessed ionic liquids

$\begin{array}{llll}\text { Ionic liquid (IL) } & \begin{array}{l}\text { Yield } \\ \text { (\%) }\end{array} & \begin{array}{l}\text { Melting } \\ \text { point }\left({ }^{\circ} \mathrm{C}\right)\end{array} \\ {\left[\mathrm{C}_{1} \mathrm{C}_{1} \mathrm{Im}\right]} & 100 & 35.8^{\mathrm{a}} \\ {\left[\mathrm{MeSO}_{4}\right]} & & \\ {\left[\mathrm{C}_{2} \mathrm{C}_{1} \mathrm{Im}\right]} & 98 & <65.0^{\mathrm{a}} \\ {\left[\mathrm{EtSO}_{4}\right]} & & & \\ & {\left[\mathrm{C}_{2} \mathrm{Py}\right]\left[\mathrm{EtSO}_{4}\right]} & 100 & \text { Unknown }\end{array}$

${ }^{a}$ www.chemicalbook.com

\section{2 | EXPERIMENTAL}

\section{1 | Materials}

All the commercial products were used as received without further purification. $n$-Hexane, acetone, and tetrahydrofuran (THF) were purchased from Carlo Erba (Milan, Italy); toluene, diethyl ether, and formic acid from Prolabo (Paris, France). 1-Methylimidazole, pyridine, diethylsulphate, dimethylsulphate and chlorobutane. Lichen metabolites standards were provided from the library of the COrInt team (University of Rennes 1).

Pseudevernia furfuracea, known as Oak moss, was collected from cedar in Morocco (Voucher JB/02/10) specimen. The lichen was identified as Pseudevernia furfuracea var. furfuracea ${ }^{2}$ according to macroscopic, microscopic, and chemical thalline reactions using potassium hydroxide $\left(\mathrm{K}^{+}\right)$, sodium hypochlorite $\left(\mathrm{C}^{-}\right)$, and with comparison to the literature. After cleaning and identification by chemical tests, the lichen was air-dried and stored in a closed glass at room temperature. 


\section{2 | Apparatus}

A CEM Explorer ${ }^{\circledR} 24$ samples with a programmable heating power (from 0 to $300 \mathrm{~W}$ ) and irradiation time was used for MAE experiments. Small-scale experiments were carried out in $10 \mathrm{~mL}$ closed glass vessels. For the scale-up process, a single-mode Synthewave ${ }^{\circledR} 1000$ Prolabo system was used with a $800 \mathrm{~mL}$ quartz vessel at an operating frequency of $2450 \mathrm{MHz}$, with a maximal output power of $300 \mathrm{~W}$ and associated to a stirring blade.

High-performance liquid chromatography (HPLC) system equipped with a Kontron 325 pump and a diode array detector (DAD), an analytical $\mathrm{C}_{18}$ Spherisorb column $(250 \mathrm{~mm} \times 4.6 \mathrm{~mm}, 5 \mu \mathrm{m})$ and with a $20 \mu \mathrm{L}$ external loop for injection was used.

Thin-layer chromatography (TLC) plates (Merk silica gel 60F254) were prepared with Camag ${ }^{\circledR}$ automatic sampler III (ATS3) and the metabolites used were quantified with Camag® TLC scanner II.

\section{3 | Synthesis of ILs}

The structures of ILs are reported in Table 1. 1,3-Dimethylimidazolium methylsulphate $\left[\mathrm{C}_{1} \mathrm{C}_{1} \mathrm{Im}\right]\left[\mathrm{MeSO}_{4}\right]$, 1-ethyl-3-methylimidazolium ethylsulphate $\left[\mathrm{C}_{2} \mathrm{C}_{1} \mathrm{Im}\right]\left[\mathrm{EtSO}_{4}\right]$, and $\mathrm{N}$-ethylpyridinium ethylsulphate $\left[\mathrm{C}_{2} \mathrm{Py}\right]\left[\mathrm{EtSO}_{4}\right]$ were synthesised following a previously reported procedure. ${ }^{24,25}$ The ILs were dried at $70^{\circ} \mathrm{C}$ under vacuum during $12 \mathrm{~h}$ and their structure was verified by proton nuclear magnetic resonance $\left({ }^{1} \mathrm{H}\right.$ NMR) (see Supporting Information, Figure S1).

\subsection{1 | 1,3-Dimethylimidazolium methylsulphate $\left[\mathrm{C}_{1} \mathrm{C}_{1} \mathrm{Im}\right]\left[\mathrm{MeSO}_{4}\right]$}

${ }^{1} \mathrm{H}-\mathrm{NMR}\left(300 \mathrm{MHz}, \mathrm{D}_{2} \mathrm{O}\right.$ ) $\delta: 8.50$ (s, $1 \mathrm{H}, \mathrm{NCHN}$ ), 7.28 (d, $2 \mathrm{H}$,

$\left.{ }^{3} \mathrm{~J}=3 \mathrm{~Hz}, \mathrm{NCHCHN}\right), 3.75\left(\mathrm{~s}, 6 \mathrm{H}, \mathrm{NCH}_{3}\right), 3.61\left(\mathrm{~s}, 3 \mathrm{H}, \mathrm{OCH}_{3}\right)$.

\subsection{2 | 1-Ethyl-3-methylimidazolium ethylsulphate $\left[\mathrm{C}_{2} \mathrm{C}_{1} \mathrm{Im}\right]\left[\mathrm{EtSO}_{4}\right]$}

${ }^{1} \mathrm{H}-\mathrm{NMR}\left(300 \mathrm{MHz}, \mathrm{CDCl}_{3}\right.$ ) $\delta: 9.23$ (s, $1 \mathrm{H}, \mathrm{NCHN}$ ), 7.42 (d, $2 \mathrm{H}$ ${ }^{3} \mathrm{~J}=3 \mathrm{~Hz}, \mathrm{NCHCHN}$ ), 4.13 (q, $2 \mathrm{H},{ }^{3} \mathrm{~J}=7.35 \mathrm{~Hz}, \mathrm{NCH}_{2}$ ), 3.93 (q, $2 \mathrm{H}$, $\left.{ }^{3} \mathrm{~J}=7.05 \mathrm{~Hz}, \mathrm{OCH}_{2}\right), 3.82\left(\mathrm{~s}, 3 \mathrm{H}, \mathrm{NCH}_{3}\right), 1.37\left(\mathrm{t}, 3 \mathrm{H},{ }^{3} \mathrm{~J}=7.5 \mathrm{~Hz}\right.$, $\mathrm{OCH}_{2} \underline{\mathrm{CH}}_{3}$ ), 1.08 (t, 3H, ${ }^{3} \mathrm{~J}=7.0 \mathrm{~Hz}, \mathrm{NCH}_{2} \underline{\mathrm{CH}}_{3}$ ).

\subsection{3 $\quad \mathrm{N}$-Ethylpyridinium ethylsulphate $\left[\mathrm{C}_{2} \mathrm{Py}\right]$ $\left[\mathrm{EtSO}_{4}\right]$}

${ }^{1} \mathrm{H}-\mathrm{NMR}\left(300 \mathrm{MHz}, \mathrm{CDCl}_{3}\right) \delta: 9.15\left(\mathrm{~d}, 2 \mathrm{H},{ }^{3} \mathrm{~J}=6 \mathrm{~Hz}, \mathrm{CHN}\right), 8.42(\mathrm{t}$, $1 \mathrm{H},{ }^{3} \mathrm{~J}=7.6 \mathrm{~Hz}, \mathrm{NCHCHC} \underline{\mathrm{H}}$ ), $7.99\left(\mathrm{t}, 2 \mathrm{H},{ }^{3} \mathrm{~J}=7 \mathrm{~Hz}, \mathrm{NCHC} \underline{\mathrm{H}}\right.$ ), 4.71 (q, $2 \mathrm{H},{ }^{3} \mathrm{~J}=7 \mathrm{~Hz}, \mathrm{NCH}_{2}$ ), 3.92 (q, $2 \mathrm{H},{ }^{3} \mathrm{~J}=7 \mathrm{~Hz}, \mathrm{OCH}_{2}$ ), 1.55 (t, $3 \mathrm{H}$, $\left.{ }^{3} \mathrm{~J}=7 \mathrm{~Hz}, \mathrm{OCH}_{2} \underline{\mathrm{CH}}_{3}\right), 1.10\left(\mathrm{t}, 3 \mathrm{H},{ }^{3} \mathrm{~J}=7 \mathrm{~Hz}, \mathrm{NCH}_{2} \underline{\mathrm{CH}}_{3}\right)$.

\section{$2.4 \quad$ Lichen sample preparation}

Pseudevernia furfuracea was collected from Montpellier. After cleaning and identification according to chemical thalline reactions, a voucher specimen (reference JB/02/10) was deposited in the herbarium of COrInt team, Rennes, France.

The grinding of the lichen samples was performed following a described method ${ }^{14}$ either with a blender to obtain mixed samples or with a planetary milled system to obtain milled samples.

\section{5 | MAE procedure}

IL-MAE process was performed using the CEM Explorer ${ }^{\circledR} 24$. Briefly, $250 \mathrm{mg}$ of milled or mixed Pseudevernia furfuracea were added to $5 \mathrm{~mL}$ of $\mathrm{IL}$ or acetone and irradiated under microwave for $15 \mathrm{~min}$ at $75^{\circ} \mathrm{C}$ and $20 \mathrm{~W}$. These quantities refer to the optimal conditions, previously published by our group. ${ }^{22}$ After irradiation, the samples were cooled down to $50^{\circ} \mathrm{C}$. The obtained extracts were filtered through cotton and separated from the entire lichen residue by $10 \mathrm{~min}$ centrifugation at $4500 \mathrm{rpm}$ using a Jouan E96 centrifuge. The acetone extracts were dried under vacuum.

A total extraction of metabolites was carried out in the same conditions using successively $n$-hexane, diethyl ether, acetone and THF. This procedure was repeated three times.

\subsection{Conventional extraction method}

Briefly, $250 \mathrm{mg}$ samples were mixed with $5 \mathrm{~mL}$ of IL and heated at $75^{\circ} \mathrm{C}$ for $24 \mathrm{~h}$ under stirring (900 rpm) using a Carrousel Radley ${ }^{\circledR}$. The samples were cooled down to $50^{\circ} \mathrm{C}$. The resulting extracts were filtered through cotton and separated from the entire lichen residue by $10 \mathrm{~min}$ centrifugation at $4500 \mathrm{rpm}$.

\section{7 | Recovery of compounds, analysis and quantification}

\subsection{1 | Recovery}

After the extraction process, the metabolites were isolated from the filtered extracts $(2 \mathrm{~mL})$ by three times extraction using water $(1 \mathrm{~mL})$ and diethyl ether $(1 \mathrm{~mL})$. The organic fractions were collected after removing the solvent under vacuum. The final aqueous extracts were analysed by HPLC using the method detailed earlier, the dried organic extract was dissolved in acetone $(1 \mathrm{mg} / \mathrm{mL})$ and then analysed by TLC coupled to a spectrophotodensitometer following the procedure described later. All procedures were repeated three times to determine the repeatability of the results. 


\subsection{2 | Quantification using a spectrophotodensitometer Camag ${ }^{\circledR}$}

A standard solution of each metabolite was prepared in acetone $(0.05-0.3 \mathrm{mg} / \mathrm{mL})$. The standard solution was used for the preparation of five point on calibration curve from 0.2 to $1.2 \mu \mathrm{g}$. The linear range was from 0.01 to $0.6 \mathrm{mg} / \mathrm{mL}$. The correlation coefficient of the calibration curve for all metabolites was 0.99 . The crude extract was dissolved in acetone at $1 \mathrm{mg} / \mathrm{mL}$ and analysed following a previously reported procedure. ${ }^{14}$ The standard solutions $(4 \mu \mathrm{L})$ and the samples $(4 \mu \mathrm{L})$ were spotted on TLC in the form of band with $4 \mathrm{~mm}$ of width and positioned from the bottom of TLC plates $(20 \mathrm{~cm} \times 10 \mathrm{~cm})$ at $15 \mathrm{~mm}$ by a Camag $®$ microlitre syringe. TLC plates were eluted in two mobile phases (n-hexane/ethyl acetate/formic acid, 100:30:5 or toluene/ethyl acetate/formic acid, 70:25:5). Their retention factor (Rf) carried out in $n$-hexane/ethyl acetate/formic acid, 100:30:5 was as follows: fumarprotocetraric acid (Fum. Ac.), 0.24; Phys. Ac., 0.35; methyl- $\beta$-orcinol carboxylate (MOC), 0.52; AT, 0.65. The quantification was performed in absorbance/reflectance mode of a Camag ${ }^{\circledR}$ TLC Scanner II under ultraviolet (UV) light at 238, 252, 263 or 267 nm for Fum. Ac., AT, Phys. Ac. or MOC (see Figure S2). The extraction efficiency of the compounds in samples was defined by the determination of the extraction yields as follows:

$$
\text { yield }(\%)=\frac{\text { mass of the compound in extract }}{\text { mass of the lichen material }} \times 100
$$

The ratio in the total yield of the compounds was defined as follows:

ratio in the total yield $(\%)=\frac{\text { mass of the compound in extract }}{\text { sum of mass of the compound in extract }} \times 100$

The higher mass of compound in the sample was determined in accordance to the best extraction yield obtained using either IL, acetone or for total extraction.

\section{8 | Physicochemical measurements}

Gas adsorption measurements were performed using a previously described process. ${ }^{14}$ The contact angle between lichen sample and IL was measured using a Digidrop GBX Contact Angle Meter with videocamera system and Windrop software. After deposition of a drop on lichen sample using $4 \mu \mathrm{L}$ droplet, two measurements were performed for each sample at room temperature on the left and right sides of droplets.

\section{9 | Scale-up of extraction}

In an $800 \mathrm{~mL}$ reactor, $500 \mathrm{~mL}$ of $\left[\mathrm{C}_{2} \mathrm{Py}\right]\left[\mathrm{EtSO}_{4}\right]$ were added over $25 \mathrm{~g}$ of mixed Pseudevernia furfuracea. The mixture was irradiated using
Synthewave ${ }^{\circledR} 1000\left(75^{\circ} \mathrm{C}, 20 \mathrm{~min}\right)$. The extracts were collected by filtration over cotton and high-speed centrifugation (10000 rpm, $15 \mathrm{~min}$ ) using a Centrikon T-1170 centrifuge. The metabolites were isolated following five cycles of liquid-liquid extraction ( $5 \times$ water/ diethyl ether: $200 \mathrm{~mL} / 200 \mathrm{~mL},(\mathrm{v} / \mathrm{v}))$ and evaporation of the organic phase under vacuum for further analyses.

\section{\begin{tabular}{l|l}
2.10 & Recycling of ILs
\end{tabular}}

A supplementary back-extraction process of ILs was performed on the aqueous phase obtained after filtration to recover the organic compounds remained in this phase. Briefly, $3 \mathrm{~mL}$ of aqueous mixture of $\left[\mathrm{C}_{2} \mathrm{Py}\right]\left[\mathrm{EtSO}_{4}\right]$ and all organic compounds were eluted on silica gel chromatography using ethyl acetate (as mobile phase) to collect the remaining compounds. Subsequently, methanol was used to recover the IL. The solvents were then removed under vacuum and the collected products were analysed by HPLC.

Another experiment was carried out on a mixture of ILs and metabolites obtained after the filtration step using SPE column such as Chromafix ${ }^{\circledR} \mathrm{C} 18$ ec or Strata ${ }^{\mathrm{TM}}$ Phenyl and THF as mobile phase. For these experiments, $0.5 \mathrm{~mL}$ mixture of ILs and metabolites were deposited on the column and eluted with $2.5 \mathrm{~mL}$ THF. After centrifugation for $5 \mathrm{~min}$, ILs and THF containing metabolites were separated. THF was then removed under vacuum and the collected products were analysed by HPLC.

\subsection{HPLC analyses}

HPLC analyses were performed at room temperature on the aqueous phase of the hydrophilic ILs after filtration using $0.45 \mu \mathrm{m}$ nylon membranes. The mobile phase consisted of solvent $A(0.2 \%$ acetic acid aqueous solution) and solvent $B$ (methanol) with a $0.8 \mathrm{~mL} / \mathrm{min}$ flow rate either used with a 60:40 ratio (eluant 1 ) or with a gradient elution (eluant 2) as follows: from 0 to $10 \mathrm{~min}$ : 90:10 (A/B); from 10 to 15 min: from 90:10 to 10:90 (A/B); from 15 to $30 \mathrm{~min}$ : 10:90 (A/B), from 30 to 35 min: from 10:90 to $90: 10(A / B)$; from 35 to $45 \mathrm{~min}$ : 90:10 (A/B). The UV detection wavelengths used were 239, 254, 270,312 or $330 \mathrm{~nm}$. The volume of each injection volume was fixed to $20 \mu \mathrm{L}$. Lichen metabolite identification was carried out by comparing their retention time with corresponding peaks in the standard solution.

\subsection{2 | Cytotoxicity assay}

Cytotoxic properties of ILs and acetone were determined with a standard tetrazolium assay. ${ }^{26}$ B16 cells were seeded at 15000 cells $/ \mathrm{mL}$ and $\mathrm{HaCaT}$ cells were seeded at 17000 cells $/ \mathrm{mL}$ in RPMI1640 medium with $5 \%$ fetal calf serum (FCS) at day 0 in well-plate. Cell lines were incubated at $37^{\circ} \mathrm{C}$ in an atmosphere of $5 \%$ carbon dioxide $\left(\mathrm{CO}_{2} \mathrm{f}\right.$ during $24 \mathrm{~h}$. After this time, ILs or acetone were added at $100 \mu \mathrm{mol} / \mathrm{L}$. 
Cell growth and viability were measured after $48 \mathrm{~h}$ of incubation at $540 \mathrm{~nm}$, after adding $10 \mu \mathrm{L}$ of MTT (3-[4,5-dimethylthiazol-2-yl]2,5-diphenyltetrazolium bromide), incubation at $37^{\circ} \mathrm{C}$ for $3 \mathrm{~h}$, and dissolution of crystals with $150 \mu \mathrm{L}$ of dimethyl sulfoxide. Each experiment was repeated three times.

\section{RESULTS AND DISCUSSION}

\section{1 | Selectivity of ILs in MAE}

We highlighted previously the interest of the aromatic imidazolium cations in interacting with $\pi$-systems such as depsidones. ${ }^{22}$ Moreover, the interest of these cations to extract various lichen metabolites was recently confirmed. ${ }^{23}$ We have also reported an optimisation study ${ }^{27}$ using six imidazolium and pyridinium-based ILs for MAE from Pseudevernia furfuracea. Microwave irradiation is generally more efficient to extract the targeted lichen metabolites (Figure 1) than conventional heating. The optimal time and temperature for MAE were defined to be $75^{\circ} \mathrm{C}$ and $15 \mathrm{~min}$, leading to considerable time efficiency compared to $24 \mathrm{~h}$ for conventional heating. ${ }^{27}$ The shorter heating period allows a sufficient contact time without subjecting the lichen metabolites to degradation. Additionally, we have found that a temperature above $90^{\circ} \mathrm{C}$ leads to metabolites degradation.

We report herein the MAE efficiency of metabolites from Pseudevernia furfuracea using three hydrophilic ${ }^{27,28}$ ILs $\left[\mathrm{C}_{1} \mathrm{C}_{1} \mathrm{Im}\right]$ [ $\left.\mathrm{MeSO}_{4}\right],\left[\mathrm{C}_{2} \mathrm{C}_{1} \mathrm{Im}\right]\left[\mathrm{EtSO}_{4}\right]$, and $\left[\mathrm{C}_{2} \mathrm{Py}\right]\left[\mathrm{EtSO}_{4}\right]$ (Table 1 ) and compare them to acetone, the conventional flammable organic solvent used for lichen metabolites extraction. ${ }^{2}$ Noteworthy, few studies reported the use of pyridinium-based ILs for the extraction of natural products. A recent study exhibited for example the highest ability of [EPy]Br to extract inorganic and organic iodine compounds from Laminaria. ${ }^{29}$

According to the results depicted in Figure 2, each IL presents an affinity toward specific metabolites whereas acetone extracted two metabolites among the four targeted ones: AT (with a high rate of $0.91 \%$ ) and Phys. Ac. (0.67\%). Concerning the MOC extraction, the highest extracted quantity was achieved using $\left[\mathrm{C}_{2} \mathrm{C}_{1} \mathrm{Im}\right]\left[\mathrm{EtSO}_{4}\right]$ as extraction solvent (0.31\%) (Figure 2). This amount decreased by around $40 \%(0.31 \%$ vs. $0.21 \%$ and $0.18 \%)$ for $\left[\mathrm{C}_{1} \mathrm{C}_{1} \mathrm{Im}\right]\left[\mathrm{MeSO}_{4}\right]$ and
$\left[\mathrm{C}_{2} \mathrm{Py}\right]\left[\mathrm{EtSO}_{4}\right]$ and around $85 \%$ for acetone (0.04\%) (Table 2). Interestingly, a total extraction of $\mathrm{MOC}$ using four successive solvents (see earlier) was as efficient as $\left[\mathrm{C}_{2} \mathrm{C}_{1} \mathrm{Im}\right]\left[\mathrm{EtSO}_{4}\right]$ (Table 2). In contrast, AT extraction with all the tested ILs was less effective compared to those with acetone or total extraction due to its easier degradation under ILs. Indeed, the low stability of AT metabolite under various extraction conditions is well known. ${ }^{30}$ However, the extraction of Phys. Ac., Fum. Ac. and AT was efficient using $\left[\mathrm{C}_{2} \mathrm{Py}\right]\left[\mathrm{EtSO}_{4}\right]$ with $0.66 \%, 0.16 \%$ and $0.26 \%$, respectively (Figure 2 ). These extractions were nine to five times lower with $\left[\mathrm{C}_{1} \mathrm{C}_{1} \mathrm{Im}\right]\left[\mathrm{MeSO}_{4}\right]$ (Figure 2) and they were not possible or very weak (for Fum. Ac.) using $\left[\mathrm{C}_{2} \mathrm{C}_{1} \mathrm{Im}\right]\left[\mathrm{EtSO}_{4}\right]$. Moreover $\left[\mathrm{C}_{2} \mathrm{Py}\right]\left[\mathrm{EtSO}_{4}\right]$ was as effective as acetone for Phys. Ac. and exhibited a higher efficiency for Fum. Ac. (Table 2). These features can be attributed to the stronger interactions with targeted analytes using pyridinium cation including $\pi$-stacking, hydrogen bonding and ionic interactions as already described. ${ }^{29}$ A simple modification of the anion-cation association can thus modify the IL physicochemical properties. Consequently, two ILs with different structures but similar or close polarity give rise to distinct results when used as extraction solvents. ${ }^{31}$ Modifying the IL structure affected the interactions between anion and cations of these salts on the one hand, and between the salts and metabolites which changed the lichen metabolites extraction potential of IL(s) on the other hand.

Moreover, we have evaluated the impact of these ILs and acetone at $100 \mu \mathrm{mol} / \mathrm{L}$ on the cell viability of B16 (a murine melanoma cell line) and $\mathrm{HaCaT}$ (a human keratinocyte cell line) (see Figure S3). The three ILs exhibited no toxicity (around 99\% cell viability for the two cell lines after IL treatment) while acetone showed $21 \%$ inhibition of viability of $\mathrm{HaCaT}$ cells.

\section{2 | Impact of lichen sample preparation}

We demonstrated previously the importance of lichen preparation on the AT extraction efficiency using acetone in favour to the mixing of lichens with blender process. ${ }^{14}$ The impact of lichen sample preparation method (milled or mixed) on the IL-MAE efficiency of metabolites is assessed, in this study, using the two imidazolium-based IL $\left[\mathrm{C}_{1} \mathrm{C}_{1} \mathrm{Im}\right]$ $\left[\mathrm{MeSO}_{4}\right]$ and $\left[\mathrm{C}_{2} \mathrm{C}_{1} \mathrm{Im}\right]\left[\mathrm{EtSO}_{4}\right]$ (Figure 3 ) which exhibited the least
FIGURE 2 Extraction rate (\%) of targeted metabolites from milled lichens using MAE with $\left[\mathrm{C}_{1} \mathrm{C}_{1} \mathrm{Im}\right]\left[\mathrm{MeSO}_{4}\right]$, $\left[\mathrm{C}_{2} \mathrm{C}_{1} \mathrm{Im}\right]\left[\mathrm{EtSO}_{4}\right],\left[\mathrm{C}_{2} \mathrm{Py}\right]\left[\mathrm{EtSO}_{4}\right]$ and acetone

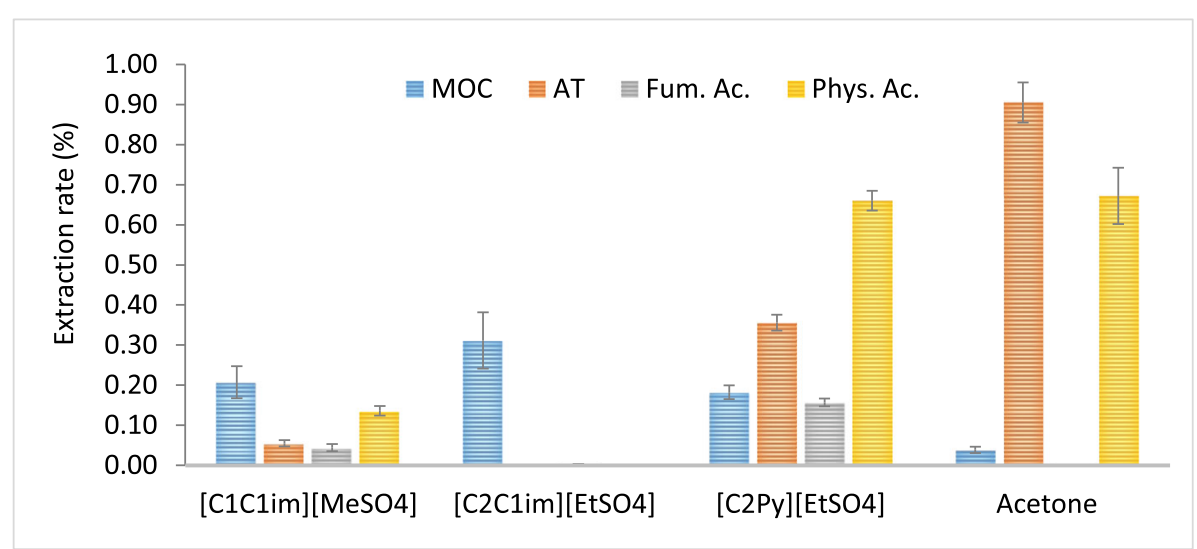


TAB LE 2 Comparative study of extraction efficiency of lichen metabolites using different solvents expressed as ratio in total yield (\%)

\begin{tabular}{lllcrr} 
& \multicolumn{2}{l}{ Ratio in total yield (\%) } \\
\cline { 2 - 6 } Compound & {$\left[\mathrm{C}_{1} \mathrm{C}_{1} I \mathrm{~m}\right]\left[\mathrm{MeSO}_{4}\right]$} & {$\left[\mathrm{C}_{2} \mathrm{C}_{1} I \mathrm{~m}\right]\left[\mathrm{EtSO}_{4}\right]$} & {$\left[\mathrm{C}_{2}\right.$ Py] $\left[\mathrm{EtSO}_{4}\right]$} & Acetone & Total extraction \\
\hline MOC & 66 & 100 & 58 & 12.5 & 66 \\
AT & 47.5 & 0 & 31 & 78 & 100 \\
Fum. Ac. & 28 & 2 & 100 & 0.6 & 11 \\
Phys. Ac. & 20 & 0 & 98 & 100 & 33 \\
\hline
\end{tabular}

$\left[\mathrm{C}_{1} \mathrm{C}_{1} \mathrm{Im}\right]\left[\mathrm{MeSO}_{4}\right], 1$,3-dimethylimidazolium methylsulphate; $\left[\mathrm{C}_{2} \mathrm{C}_{1} \mathrm{Im}\right]\left[\mathrm{EtSO}_{4}\right]$, 1-ethyl-3-methylimidazolium ethylsulphate; $\left[\mathrm{C}_{2} \mathrm{Py}\right]\left[\mathrm{EtSO} \mathrm{C}_{4}\right], \mathrm{N}$ ethylpyridinium ethylsulphate; MOC, methyl- $\beta$-orcinol carboxylate; AT, atranorin; Fum. Ac., fumarprotocetraric acid; Phys. Ac., physodic acid.

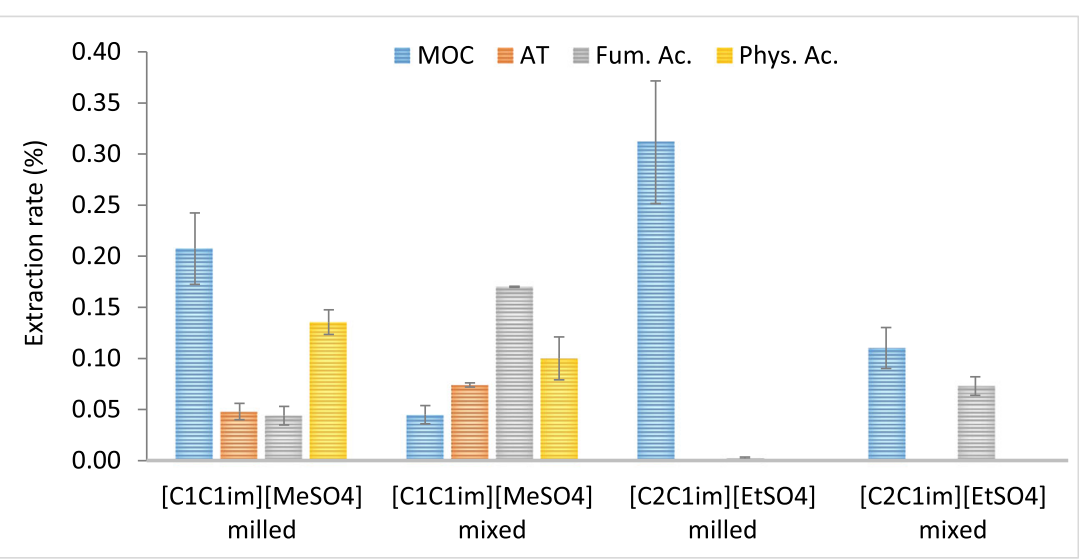

FIGURE 3 Extraction rate (\%) of targeted metabolites using MAE combined to $\left[\mathrm{C}_{1} \mathrm{C}_{1} \mathrm{Im}\right]$ $\left[\mathrm{MeSO}_{4}\right]$ and $\left[\mathrm{C}_{2} \mathrm{C}_{1} \mathrm{Im}\right]\left[\mathrm{EtSO}_{4}\right]$ on milled or mixed samples

ability to extract AT. This latter metabolite was slightly better extracted using $\left[\mathrm{C}_{1} \mathrm{C}_{1} \mathrm{Im}\right]\left[\mathrm{MeSO}_{4}\right]$ from mixed lichen $(0.074 \%)$ than from milled lichen $(0.048 \%)$, whereas, it was not extracted using $\left[\mathrm{C}_{2} \mathrm{C}_{1} \mathrm{Im}\right]\left[\mathrm{EtSO}_{4}\right]$. In contrast, Fum. Ac. was more efficiently extracted from mixed sample using both $\left[\mathrm{C}_{1} \mathrm{C}_{1} \mathrm{Im}\right]\left[\mathrm{MeSO}_{4}\right]$ and $\left[\mathrm{C}_{2} \mathrm{C}_{1} \mathrm{Im}\right]$ $\left[\mathrm{EtSO}_{4}\right]$. The extraction rate of Fum. Ac. using $\left[\mathrm{C}_{1} \mathrm{C}_{1} \mathrm{Im}\right]\left[\mathrm{MeSO} \mathrm{S}_{4}\right]$ increased from $0.044 \%$ for the milled lichen to $0.170 \%$ for the mixed one. Upon using $\left[\mathrm{C}_{2} \mathrm{C}_{1} \mathrm{Im}\right]\left[\mathrm{EtSO}_{4}\right]$, the rates increased from $0.03 \%$ to $0.073 \%$, respectively. By contrast, an opposite trend was observed for the extraction rate of $\mathrm{MOC}$ with these two ILs from milled and mixed samples. A decrease from $0.21 \%$ to $0.045 \%$ was calculated for $\left[\mathrm{C}_{1} \mathrm{C}_{1} \mathrm{Im}\right]\left[\mathrm{MeSO}_{4}\right]$ and from $0.31 \%$ to $0.11 \%$ for $\left[\mathrm{C}_{2} \mathrm{C}_{1} \mathrm{Im}\right]\left[\mathrm{EtSO} \mathrm{H}_{4}\right]$. Finally using the less selective $\left[\mathrm{C}_{1} \mathrm{C}_{1} \mathrm{Im}\right]\left[\mathrm{MeSO}_{4}\right]$, a relatively small increase of extraction rate was observed for Phys. Ac. using the milling process $(0.136 \%)$ vs, the mixing process $(0.100 \%)$.

These results confirm that the mixing process yielded less fine powders than the milling process but with larger specific surface area and pore volume ${ }^{14}$ which are more favourable for AT and Fum. Ac. extraction, regardless of the solvents used (acetone or ILs). The extraction rate of Phys. Ac. was nevertheless less impacted by the grinding process.

\subsection{Scale-up of the process and IL back- extraction procedure}

The detailed process for the 100 times scale-up, described in Figure 4, was performed on $25 \mathrm{~g}$ of mixed lichen sample keeping the same liquid/solid ratio used for the small scale. An additional step (step 2) was incorporated to achieve a better performance of the process: a manual stirring before MAE to ensure a better homogenisation of solution. The other steps are similar to those used for small-scale extraction: filtration on cotton at $50^{\circ} \mathrm{C}$ to avoid clogging on filters due to the viscosity of IL (step 4), centrifugation to separate the different phases (step 5), and liquid extraction using an organic phase nonmiscible with IL in order to concentrate extracted metabolites (step 6) before quantification using a Camag ${ }^{\circledR}$ spectrophotodensitometer.

In order to verify the good repeatability between the small-scale extraction and scaling-up on mixed sample which highly impacts Fum. Ac. extraction, we have first chosen the most selective imidazoliumbased IL $\left[\mathrm{C}_{2} \mathrm{C}_{1} \mathrm{Im}\right]\left[\mathrm{EtSO}_{4}\right]$. This IL could only extract $\mathrm{MOC}$ and Fum. Ac. The same trends were observed for the scale-up compared to the small scale. Extraction rates of $0.31 \%$ (vs. $0.28 \%$ ) and $0.21 \%$ (vs. $0.18 \%$ ) for MOC and Fum. Ac. were recorded. Noteworthy, no traces of AT were detected in any of the cases.

We have then extended this process on mixed sample using the most efficient pyridinium-based $\mathrm{IL},\left[\mathrm{C}_{2} \mathrm{Py}\right]\left[\mathrm{EtSO}_{4}\right]$. Contact angles measured between this hydrophilic IL on milled or mixed lichens were identical $\left(102^{\circ}\right)$ indicating a very light wettability of lichens using this IL, regardless of the grinding method used. We have thus hypothesised that, in accordance to these latter results and to those reported on surface area earlier, the extraction from mixed lichen using this IL would be more efficient.

As already observed earlier, the mixing process was more favourable for AT and Fum. Ac. extraction than milled process with an extraction rate of $0.85 \%$ for AT and $0.75 \%$ for Fum. Ac. The extraction 


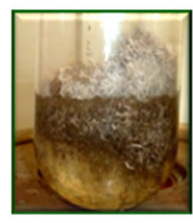

$500 \mathrm{~mL} \mathrm{IL}+25 \mathrm{~g}$ mixed Lichen

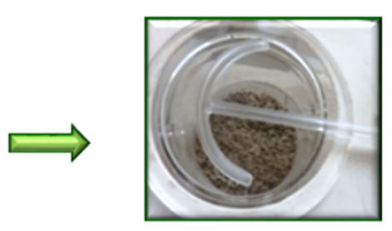

Manual stirring

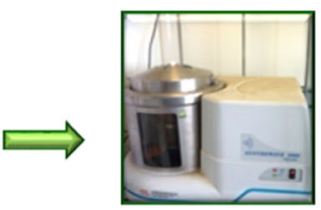

MAE $75^{\circ} \mathrm{C}, 20 \mathrm{~W}, 20 \mathrm{~min}$

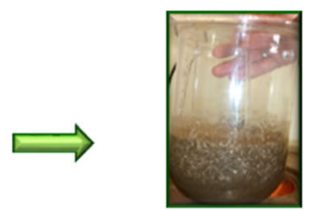

Extract + Lichen powder + IL
QUANTIFICATION using CAMAG®
Evaporation of organic phase

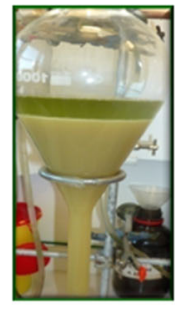

Liquid - Liquid extraction (water: diethyl ether, 5 times)

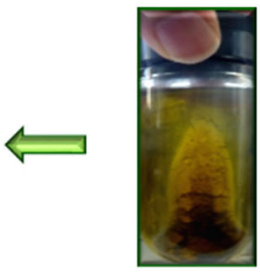

Centrifugation (10 $000 \mathrm{rpm}, 20 \mathrm{~min}$ )

FIGURE 4 Scale-up process performed on $25 \mathrm{~g}$ mixed sample with $500 \mathrm{~mL}$ ILs

FIGURE 5 HPLC chromatograms of extract of $\left[\mathrm{C}_{2} \mathrm{Py}\right]\left[\mathrm{EtSO}_{4}\right]$ and metabolites (a) before and (b) after purification with small phase column (Chromafix ${ }^{\circledR} \mathrm{C} 18 \mathrm{ec}$ ) at $254 \mathrm{~nm}$ (eluant 2); AT: $28.88 \mathrm{~min}$

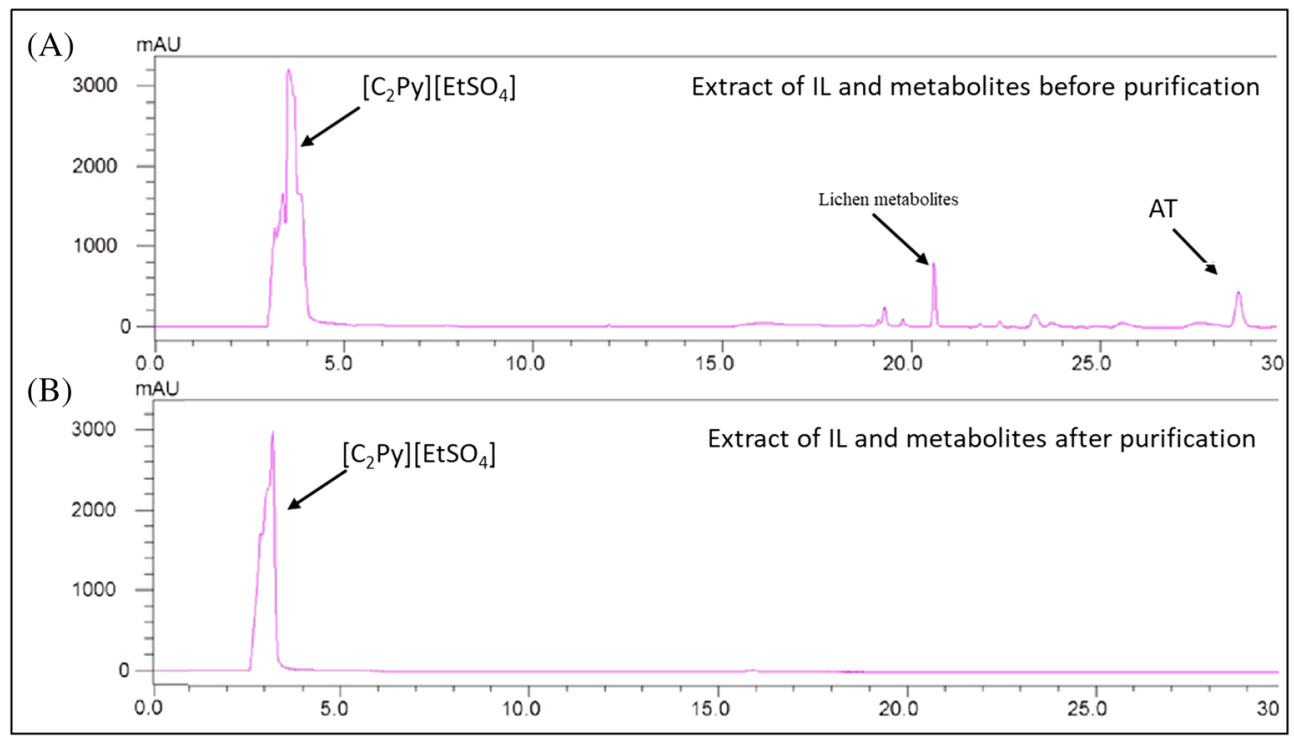

efficiency for MOC and Phys. Ac. were quite similar between the small-scale and the scale-up process, regardless of the grinding process used. These results display the interest of this pyridium-based IL for the extraction of the major metabolites from Pseudevernia furfuracea.

In both cases of scale-up, the aqueous phases obtained after liquid-liquid extraction using diethyl ether were analysed by HPLC in order to determine the eventual possibility of back-extraction of ILs used during the process. Some lichen metabolites were detected at different wavelengths highlighting the non-total recovery of the lichen extracted metabolites after liquid-liquid extraction (Figures $5 \mathrm{a}$ and S4). After a supplementary step of purification on silica gel chromatography using ethyl acetate for the elution of metabolites then methanol for the elution of ILs, we have confirmed the absence of metabolites in the back-extracted IL. This procedure which corresponds to a conventional method to separate lichen metabolites simultaneously allows the purification of lichen metabolites.

To decrease the solvent consumption used, particularly during the back-extraction, we have successfully performed this separation directly on a mixture of IL and metabolites after the filtration step using a SPE column as Chromafix ${ }^{\circledR}$ C18 ec or Strata ${ }^{\mathrm{TM}}$ Phenyl and THF as solvent. HPLC analysis exhibited a high purity of ILs (Figure $5 \mathrm{~b}$ ). With these latter experiments, we succeeded to scale- 
up the process and we finally proved the full recycling of IL to be used for further studies. Further experiments are in progress in order to improve the extraction of lichens using more eco-friendly solvents.

\section{ACKNOWLEDGEMENTS}

Special thanks to J. M Bessiere, PNSM, Montpellier for providing the lichen specimen.

\section{FUNDING DECLARATION}

This research did not receive any specific grant from funding agencies in the public, commercial, or not-for-profit sectors.

\section{ORCID}

Jean-Pierre Bazureau (D) https://orcid.org/0000-0003-3053-3425 Sophie Tomasi (D) https://orcid.org/0000-0001-9827-527X

\section{REFERENCES}

1. Nash T III. Lichen Biology. Cambridge: Cambridge University Press; 2008:498.

2. Huneck S. Identification of Lichen Substances. 493 Berlin: SpringerVerlag; 2012.

3. Joulain D, Tabacchi R. Lichen Extracts as Raw Materials in Perfumery. Part 1: Oakmoss. Flavour Fragr J. 2009;24(2):49-61. https://doi.org/ 10.1002/ffj.1916

4. Crawford SD. Lichens used in traditional medicine. In: Lichen Second ary Metabolites. Berlin: Springer; 2015:27-80.

5. Shukla V, Joshi GP, Rawat MSM. Lichens as a potential natural source of bioactive compounds: A review. Phytochem Rev. 2010;9(2): 303-314. https://doi.org/10.1007/s11101-010-9189-6

6. Molnár K, Farkas E. Current results on biological activities of lichen secondary metabolites: A review. Z Für Naturforschung C. 2010;65 (3-4):157-173. https://doi.org/10.1515/znc-2010-3-401

7. Shrestha G, St. Clair LL. Lichens: A promising source of antibiotic and anticancer drugs. Phytochem Rev. 2013;12(1):229-244. https://doi. org/10.1007/s11101-013-9283-7

8. Calcott MJ, Ackerley DF, Knight A, Keyzers RA, Owen JG. Secondary metabolism in the lichen symbiosis. Chem Soc Rev. 2018;47(5):17301760. https://doi.org/10.1039/C7CS00431A

9. Ventura SPM, E Silva FA, Quental MV, Mondal D, Freire MG, Coutinho JAP. Ionic-liquid-mediated extraction and separation processes for bioactive compounds: Past, present, and future trends. Chem Rev. 2017;117(10):6984-7052. https://doi.org/10.1021/acs. chemrev.6b00550

10. Ullah H, Wilfred CD, Shaharun MS. Ionic liquid-based extraction and separation trends of bioactive compounds from plant biomass. Sep Sci Technol. 2019;54(4):559-579. https://doi.org/10.1080/01496395. 2018.1505913

11. Xiao J, Chen G, Li N. Ionic liquid solutions as a green tool for the extraction and isolation of natural products. Molecules. 2018;23(7): 1765. https://doi.org/10.3390/molecules23071765

12. Zhou J, Sui H, Jia Z, Yang Z, He L, Li X. Recovery and purification of ionic liquids from solutions: A review. RSC Adv. 2018;8(57):3283232864. https://doi.org/10.1039/C8RA06384B

13. Joulain $D$, Tabacchi R. Lichen extracts as raw materials in perfumery. Part 2: treemoss. Flavour Fragr J. 2009;24(3):105-116. https://doi. org/10.1002/ffj.1923

14. Komaty S, Letertre M, Dang HD, et al. Sample preparation for an optimized extraction of localized metabolites in lichens: Application to
Pseudevernia furfuracea. Talanta. 2016;150:525-530. https://doi.org/ 10.1016/j.talanta.2015.12.081

15. Güvenç A, Küpeli Akkol E, Süntar I, Keleş H, Yıldız S, Çalış i. Biological activities of Pseudevernia furfuracea (L.) Zopf extracts and isolation of the active compounds. J Ethnopharmacol. 2012;144(3):726-734. https://doi.org/10.1016/j.jep.2012.10.021

16. Mitrovi T. Plastimatia glauca and Pseudevernia furfuracea lichens as sources of antioxidant, antimcrobial and antibiofilm agents. EXCLI J. 2014;3:938-953.

17. Šeklić DS, Obradović AD, Stanković MS, et al. Proapoptotic and antimigratory effects of Pseudoevernia furfuraceae and Platismatia glauca on colon cancer cell lines. Food Technol Biotechnol. 2018;56(3):421430. https://doi.org/10.17113/ftb.56.03.18.5727

18. Türk H, Yılmaz M, Tay T, Türk AÖ, Kıvanç M. Antimicrobial activity of extracts of chemical races of the lichen Pseudevernia furfuracea and their physodic acid, chloroatranorin, atranorin, and olivetoric acid constituents. Z Für Naturforschung C. 2006;61(7-8):499-507. https:// doi.org/10.1515/znc-2006-7-806

19. Studzinska-Sroka E, Galanty A, Bylka W. Atranorin - an interesting lichen secondary metabolite. Mini-Rev Med Chem. 2017;17(17):16331645. https://doi.org/10.2174/1389557517666170425105727

20. Bauer J, Waltenberger B, Noha SM, et al. Discovery of depsides and depsidones from lichen as potent inhibitors of microsomal prostaglandin E2 synthase-1 using pharmacophore models. ChemMedChem. 2012;7(12):2077-2081. https://doi.org/10.1002/cmdc.201200345

21. Emsen B, Togar B, Turkez H, Aslan A. Effects of two lichen acids isolated from Pseudevernia furfuracea (L.) Zopf in cultured human lymphocytes. Z Für Naturforschung C. 2018;73(7-8):303-312. https://doi. org/10.1515/znc-2017-0209

22. Bonny S, Paquin L, Carrié D, Boustie J, Tomasi S. Ionic liquids based microwave-assisted extraction of lichen compounds with quantitative spectrophotodensitometry analysis. Anal Chim Acta. 2011;707(1-2): 69-75. https://doi.org/10.1016/j.aca.2011.09.009

23. Calla-Quispe E, Robles J, Areche C, Sepulveda B. Are ionic liquids better extracting agents than toxic volatile organic solvents? A combination of ionic liquids, microwave and LC/MS/MS, applied to the lichen Stereocaulon glareosum. Front Chem. 2020;8:450. https://doi.org/10. 3389/fchem.2020.00450

24. Holbrey JD, Reichert WM, Swatloski RP, et al. Efficient, halide free synthesis of new, low cost ionic liquids: 1,3-dialkylimidazolium salts containing methyl- and ethyl-sulfate anions. Green Chem. 2002;4(5): 407-413. https://doi.org/10.1039/b204469b

25. González B, Calvar N, Gómez E, Domínguez I, Domínguez Á. Synthesis and physical properties of 1-ethylpyridinium ethylsulfate and its binary mixtures with ethanol and 1-propanol at several temperatures. J Chem Eng Data. 2009;54(4):1353-1358. https://doi.org/10.1021/ je800981d

26. Millot M, Tomasi S, Studzinska E, Rouaud I, Boustie J. Cytotoxic constituents of the lichen Diploicia canescens. J Nat Prod. 2009;72(12): 2177-2180. https://doi.org/10.1021/np9003728

27. Gauffre F, Tomasi S, Paquin L. Ionic liquids coupled to microwave irradiation: An efficient and selective process for secondary lichens metabolites extraction. In: Proceedings of 1st International Electronic Conference on Medicinal Chemistry. MDPI; 2015:A026. https://doi. org/10.3390/ecmc-1-A026

28. Wasserscheid P, Welton T. lonic Liquids in Synthesis. 2nd ed. 1 Weinheim: Wiley- $\mathrm{VCH} ; 2008$.

29. Peng L-Q, Yu W-Y, Xu J-J, Cao J. Pyridinium ionic liquid-based liquidsolid extraction of inorganic and organic iodine from Laminaria. Food Chem. 2018;239:1075-1084. https://doi.org/10.1016/j.foodchem. 2017.07.031

30. Vos C, McKinney P, Pearson C, Heiny E, Gunawardena G, Holt EA. The optimal extraction and stability of atranorin from lichens, in rela- 
tion to solvent and $\mathrm{pH}$. The Lichenologist. 2018;50(4):499-512. https://doi.org/10.1017/S0024282918000075

31. Anderson JL, Ding J, Welton T, Armstrong DW. Characterizing ionic liquids on the basis of multiple solvation interactions. J Am Chem Soc. 2002;124(47):14247-14254. https://doi.org/10.1021/ ja028156h

\section{SUPPORTING INFORMATION}

Additional supporting information may be found online in the Supporting Information section at the end of this article.
How to cite this article: Komaty S, Sauvager A, Bazureau J-P, Tomasi S, Paquin L. Efficiency and selectivity of ionic liquids in microwave-assisted extraction of major lichen phenolic compounds: a scalable process with recycling of ionic liquids. Phytochemical Analysis. 2020;1-9. https://doi.org/10.1002/ pca.3008 